\title{
Tinjauan Etik Regulasi Jam Kerja Dokter di Indonesia
}

\author{
Mohammad Baharuddin ${ }^{1,2}$, Reggy Lefrandt ${ }^{1,3}$, Frans Santosa ${ }^{\mathrm{I}, 4}$ \\ ${ }^{1}$ Majelis Kehormatan Etik Kedokteran Pengurus Besar Ikatan Dokter Indonesia \\ ${ }^{2}$ Departemen Obstetri dan Ginekologi, Rumah Sakit Bersalin Budi Kemuliaan, Jakarta \\ 3.Departemen Kardiologi dan Kedokteran Vaskular, Fakultas Kedokteran Universitas Sam Ratulangi, Manado, Sulawesi Utara \\ ${ }^{4}$ Departemen Angiologi Vaskular, Fakultas Kedokteran Universitas Pembangunan Nasional "Veteran" Jakarta
}

\begin{abstract}
Kata Kunci
etika kedokteran; jam kerja

Korespondensi
baharbk@yahoo.com
contact@ilmiah.id
Publikasi
C 2017 JEKI/ilmiah.id
DOI
I0.26880/jeki.viir.6
\end{abstract}

Tanggal masuk: 8 Juli 2017

Tanggal ditelaah: 25 Juli 2017

Tanggal diterima: ${ }_{5}$ Agustus 2017

Tanggal publikasi: II Oktober 2017

\begin{abstract}
Abstrak Jumlah jam kerja dokter yang dipandang berlebihan sudah menjadi sorotan nasional dan internasional dalam beberapa waktu terakhir. Banyaknya jumlah jam kerja berbanding lurus dengan beban kerja dokter yang besar. Beberapa hal yang diduga menjadi penyebab peningkatan beban kerja dokter, antara lain jumlah pasien yang meningkat, persebaran dokter yang tidak merata, kompleksitas penyakit pasien yang semakin tinggi, serta jumlah proyek penelitian dokter yang semakin banyak. Kurangnya apresiasi terhadap profesi dokter juga diduga sebagai pemicu pengaturan jumlah kerja dokter yang berlebihan. Meningkatnya beban kerja dapat berdampak negatif pada keselamatan dokter dan pasien pada jam kerja, yang dapat berujung pada peningkatan gugatan medis. Oleh karena itu, diperlukan sistem kerja serta kebijakan yang jelas dan efektif untuk mengatur jumlah jam kerja dokter.
\end{abstract}

Abstract The excessive amount of physician working hours has been the national and international spotlight
in recent times. The amount of working hours is directly proportional to the large doctor's workload. There
are several things suspected as the cause of increasing workload of doctors, including increasing patient num-
bers, uneven physician distribution, increasing complexity of patient disease, and increasing number of doctor
research projects. Lack of appreciation for medical profession is also suspected as one trigger which increases
the excessive doctor work. Increased workload can negatively impact the safety of doctors and patients during
working hours, which can lead to increased medical claims. Therefore, a clear and effective working system and
policy is required to regulate the amount of physician working hours.

\section{PENDAHULUAN}

Jam kerja yang lama dan beban kerja yang tak terduga sudah menjadi bagian yang tak terpisahkan dari profesi dokter. Kasus-kasus yang terjadi beberapa waktu terakhir di Indonesia membuat jam kerja dokter menjadi sorotan nasional. Pada Januari 2017, media nasional sempat digemparkan dengan aksi seorang bupati yang menegur keras dokter dan perawat yang tertidur saat jam kerja. Hal tersebut terjadi saat Gubernur melakukan inspeksi mendadak (sidak) di salah satu rumah sakit setelah adanya laporan dari masyarakat mengenai kurang baiknya kinerja rumah sakit tersebut. ${ }^{1}$ Amarah Gubernur kemudian menjadi kontroversi ketika di satu sisi argumen tentang penyalahan tanggung jawab tenaga kesehatan yang tertidur di jam kerja membenarkan sikap Gubernur, sementara di sisi lain argumen tentang hak seorang dokter untuk memelihara kesehatan diri sendiri seharusnya menjadi pertimbangan Gubernur sebelum bersikap berlebihan tersebut.

Baru-baru ini, meninggalnya seorang dokter anestesi saat bertugas di rumah sakit kembali menuai ungkapan duka cita dari sejawat dokter dan masyarakat. ${ }^{2}$ Meski sudah diklarifikasi bahwa penyebab kematian dokter tersebut bukan diakibatkan oleh jam kerja yang berlebihan, kasus tersebut tetap menimbulkan pertanyaan: bagaimana sebenarnya pengaturan jam kerja dokter di Indonesia?

\section{METODE}

Informasi dan data penunjang dikumpulkan melalui penelusuran literatur di basis data jurnal PubMed dan Journal of Psychology and Psychotherapy dengan kata kunci "work hour", 
"doctors", dan "workload"; situs web surat kabar daring Antara News; situs web Kementerian Kesehatan Republik Indonesia dan Ikatan Dokter Indonesia; serta Kode Etik Kedokteran Indonesia. Jurnal dan artikel yang digunakan sebagai dasar penulisan publikasi ini terbit antara tahun 2001. 2017.

\section{HASIL DAN PEMBAHASAN}

\section{Penyebab Beban Kerja Dokter yang Berlebihan}

Tidak dapat dipungkiri, terdapat perbedaan jam kerja yang cukup terlihat antara dokter klinik dengan dokter non-klinik. Jam kerja dokter yang lama disebabkan oleh beban kerja dokter yang besar. Beban kerja seyogyanya dikaitkan dengan jumlah penduduk suatu negara. Berdasarkan data dari Kementerian Kesehatan, rasio dokter dengan penduduk Indonesia pada tahun 2014 adalah 1 : 2538. Rasio tersebut masih belum mencapai batas ideal WHO yang menetapkan rasio 1 : 1000. Dari 95.976 dokter yang teregistrasi, 17.507 diantaranya bekerja di Puskesmas sehingga diperkirakan setiap Puskesmas rata-rata memiliki 1,8 dokter. Namun, kenyataannya masih ada 938 puskesmas yang kekurangan atau bahkan tidak memiliki dokter. ${ }^{3}$

Penyebab lain dari beban kerja dokter yang berlebihan di Indonesia adalah tidak meratanya persebaran dokter. Meskipun sudah mencapai standar ideal yang ditetapkan WHO, beban kerja dokter di Indonesia pada kenyataannya belum terbagi secara rata di seluruh wilayah. Memusatnya dokter-dokter di kota-kota besar menyebabkan beban kerja dokter di daerah lebih besar sehingga mengharuskannya untuk bekerja lebih lama. ${ }^{4}$

Tak hanya menjadi sorotan nasional, jam kerja dokter juga menjadi sorotan internasional. Berdasarkan data dari Royal College of General Practitioner (RCGP), jumlah konsultasi dokter umum di Inggris mengalami peningkatan sebanyak 19\% dari 303 juta konsultasi pada tahun 20082009 menjadi 361 juta konsultasi pada tahun 2013-2014. Di waktu yang sama, kompleksitas penyakit di Inggris juga meningkat. Hal tersebut ditandai dengan peningkatan jumlah pasien yang memiliki komorbiditas ganda dari 1,9 juta pasien pada tahun 2008 menjadi 2,9 juta pasien pada tahun 2018. ${ }^{5}$ Bagaimana kaitannya dengan program BPJS Kesehatan? Salah satu tujuan program BPJS Kesehatan tentunya adalah untuk meningkatkan kesadaran berobat masyarakat. Hal tersebut tentunya akan menambah jumlah kunjungan pasien dari sebelumnya yang pada akhirnya akan berujung pada peningkatan beban kerja dokter sehingga jam kerja dokter pun kian memanjang. Berdasarkan penelitian yang dilakukan oleh Wexian Xu dkk. di Cina, beban kerja dokter yang berlebihan disebabkan oleh peningkatan dokter yang tidak seimbang dengan peningkatan kunjungan pasien, tindakan operasi, dan peningkatan jumlah proyek penelitian. Peningkatan beban kerja tersebut menyebabkan gugatan medis meningkat secara signifikan dari 36 kasus pada tahun 2006 menjadi 65 kasus pada tahun $2012 .^{6}$

\section{Dampak Beban Kerja yang Berlebihan}

Beban kerja dan jam kerja yang berlebihan memiliki pengaruh yang cukup signifikan terhadap kinerja dokter dan keselamatan pasien. Berdasarkan publikasi oleh Royal College of General Practitioner (RCGP), kelelahan merupakan salah satu faktor utama dari tenaga kesehatan yang dapat membahayakan pasien. Kelelahan (fatigue) mempengaruhi konsentrasi dan kemampuan untuk menyelesaikan tugas sehingga sering menjadi akar permasalahan dari kesalahan yang dilakukan oleh dokter. Beberapa hal yang menyebabkan kelelahan pada dokter, antara lain kurang tidur dan kerja

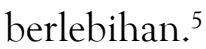

Berdasarkan publikasi oleh Lockley dkk., diketahui bahwa dokter magang yang mendapat giliran berjaga selama 24 jam melakukan 36\% lebih banyak kesalahan medis yang lebih serius dibandingkan dengan dokter yang berjaga selama 16 jam, melakukan lima kali lebih banyak kesalahan diagnosis, mengalami 61\% lebih banyak kecelakaan yang berkaitan dengan jarum atau benda tajam setelah 20 jam berjaga, meningkatkan risiko kecelakaan berkendara dua kali lipat, dan mengalami penurunan kinerja setara dengan yang ditimbulkan oleh kadar alkohol darah 0,05-0,10\%.

Melihat tendensi beban kerja yang cukup besar dalam pekerjaan seorang dokter, urgensi akan adanya pemeriksaan kesehatan umum sebelum menjadi dokter menjadi hal yang penting untuk diperhatikan oleh pihak institusi pendidikan kedokteran maupun pemerintah. Hal ini merupakan upaya deteksi dini akan risiko kesehatan calon dokter yang dapat menjadi perhatian khusus dan bahan pertimbangan dalam menjalankan profesinya ke depan. 


\section{Regulasi Jam Kerja Dokter di Negara Maju}

Regulasi jam kerja yang diadiopsi di Inggris sejak tahun 1998 adalah European Working Time Directive (EWTD), yakni sebuah kebijakan yang memuat jam kerja minimum, periode istirahat, cuti tahunan bagi para pekerja, dan pengaturan kerja bagi para pekerja malam. Untuk dokter muda yang sedang magang, diterapkan sebuah kebijakan yang disebut The New Deal. Pada tahun 2007 dan 2009, jumlah jam kerja dalam regulasi-regulasi tersebut mengalami perubahan berupa pengurangan jam kerja untuk dapat mencapai kinerja yang optimal. Hasil dari perubahan regulasi tersebut mengurangi jam kerja dokter residen dari 58 jam per minggu menjadi 56 jam per minggu. ${ }^{8,9}$

\section{Regulasi Jam Kerja Dokter di Indonesia}

Berdasarkan Keputusan Menteri Kesehatan No.81 Tahun 2004, telah ditetapkan sebuah pedoman penyusunan perencanaan sumber daya manusia kesehatan di tingkat propinsi, kabupaten/ kota, dan rumah sakit. Dalam kebijakan tersebut, dipaparkan langkah-langkah untuk menentukan standar beban kerja. Standar beban kerja adalah jumlah kegiatan pokok tiap unit kerja dalam kurun waktu 1 tahun. Jumlah kegiatan pokok disusun berdasarkan data kegiatan pelayanan yang telah dilaksanakan di tiap unit kerja rumah sakit dalam kurun waktu 1 tahun. ${ }^{10}$

Standar beban kerja ditetapkan berdasarkan waktu kerja tersedia yang dimiliki oleh masingmasing SDM dibagi waktu yang dibutuhkan untuk menyelesaikan suatu kegiatan pokok. Waktu kerja yang tersedia diperoleh dari jumlah hari kerja selama setahun dikurangi dengan hak cuti tahunan (12 hari), pendidikan dan pelatihan (6 hari), hari libur nasional, ketidakhadiran kerja, dikali dengan waktu kerja per hari. Sementara itu, waktu yang dibutuhkan untuk menyelesaikan suatu kegiatan pokok (rata-rata waktu) ditetapkan berdasarkan pengamatan dan pengalaman selama bekerja yang telah disepakati bersama. Kebutuhan waktu untuk menyelesaikan suatu kegiatan pokok sangat bervariasi dan dipengaruhi kompetensi SDM, Standar Operasional Prosedur (SOP), standar pelayanan, serta sarana dan prasarana medis yang tersedia. $^{10}$

Meskipun tidak dinyatakan dengan tegas jumlah maksimum jam kerja yang telah ditetapkan, dapat diketahui bahwa rata-rata jam kerja yang diperkenankan adalah 8 jam sehari selama 5 hari kerja per minggu. Jumlah jam kerja dapat berubah sesuai dengan kebutuhan masing-masing instansi atau unit. ${ }^{10}$ Untuk mengatur dan menentukan jumlah jam kerja dokter, terdapat nilai-nilai yang perlu dipertimbangkan dalam mengambil keputusan. Nilai-nilai tersebut terkandung dalam Kode Etik Kedokteran Indonesia (KODEKI) dan tercantum lebih spesifik dalam Pasal 2 tentang Standar Pelayanan Kedokteran Yang Baik dan Pasal 13 tentang Kerjasama. Dalam kedua pasal tersebut, dokter ditekankan untuk mempertahankan perilaku profesional dalam mengambil keputusan untuk kepentingan terbaik dan keselamatan pasien, baik dalam kerja individu maupun dalam kerjasama dengan sejawat atau pihak lain. ${ }^{11}$

\section{Struktur Kerja yang Ideal dalam Pelayanan Kesehatan}

Untuk mencapai pelayanan yang optimal, diperlukan struktur kerja yang ideal. Dokter sebagai salah satu komponen pelayanan kesehatan memegang peran yang penting, di antaranya adalah sebagai pemimpin. Dalam sebuah pedoman yang diterbitkan oleh National Health Service (NHS) Leadership Academy, London, pada tahun 2011, kepemimpinan yang baik dalam pelayanan kesehatan ditentukan oleh kualitas pribadi yang mumpuni di mana potensi tersebut dapat dideteksi melalui uji psikotes calon mahasiswa kedokteran. Selain itu, kepemimpinan yang baik juga ditentukan oleh berbagai macam kemampuan lainnya, seperti kerja sama, manajemen dan peningkatan pelayanan, menciptakan visi, dan menyusun strategi. ${ }^{12}$

Pemimpin yang kompeten adalah pemimpin yang memiliki integritas, sikap mawas diri, kontrol emosi, dan keinginan untuk senantiasa mengembangkan diri. Dalam bekerja sama, pemimpin yang baik mampu membangkitkan kontribusi anggota, membangun dan menjaga hubungan yang baik dengan anggota maupun pihak lain, serta memahami dengan jelas peran dirinya dan anggota lainnya. Untuk menciptakan pelayanan yang teratur, pemimpin dituntut untuk memimpin perencanaan dengan aktif, meminta umpan balik dari anggota lain, mengatur sumber daya yang ada, dan mengatur eksekusi pelayanan. Selama proses eksekusi, pemimpin juga perlu memastikan keselamatan pasien dan mengevaluasi hasil eksekusi secara berkala. Dari hasil evaluasi tersebut, pemimpin 
menampung aspirasi dan inovasi yang disampaikan oleh anggota dan kemudian memfasilitasi terjadinya transformasi. ${ }^{12}$

Dalam sebuah publikasi, Royal College of General Practitioners (RCGP) memberikan beberapa rekomendasi untuk mengurangi beban kerja dokter umum, antara lain dengan menyederhanakan birokrasi, membatasi jumlah pasien dalam sehari, membatasi jumlah jam kerja tenaga kesehatan, mengatur jumlah jam istirahat tenaga kesehatan, dan menyusun sebuah sistem yang dapat mengidentifikasi adanya praktik yang dilakukan di bawah tekanan ekstrim. ${ }^{5}$ Meskipun demikian, peran pihak disiplin ilmu atau departemen memang cukup signifikan dalam menentukan beban kerja dokter.

\section{KESIMPULAN}

Meskipun sudah ada aturan dan kode etik yang dapat digunakan sebagai dasar pembuatan perencanaan jumlah jam kerja, diperlukan kebijakan yang lebih spesifik dan efektif dalam menentukan jumlah jam kerja. Dengan adanya regulasi jam kerja yang efektif, kinerja dokter di pelayanan kesehatan diharapkan dapat mengalami peningkatan. Selain itu, direkomendasikan agar institusi pendidikan dapat memasukkan pemeriksaan kesehatan umum bagi mahasiswa sebelum menjadi dokter dalam upaya menghindari adanya kejadian yang tidak diinginkan di kemudian hari yang terkait dengan pekerjaan sebagai dokter.

\section{KONFLIK KEPENTINGAN}

Tidak ada konflik kepentingan.

\section{REFERENSI}

1. Saputra D. Gubernur Zumi Zola marah temui dokter jaga tidur di RSUD Raden Mattaher [Internet]. ANTARA News. 2017 Jan 20 [disitasi 2017 Jul 6]. Diunduh dari: http://www.antaranews. com/berita/608022/gubernur-zumi-zola-marahtemui-dokter-jaga-tidur-di-rsud-raden-mattaher

2. Kementerian Kesehatan Republik Indonesia. Tanggapan Kemenkes atas meninggalnya

Dokter Stefanus Taofik [Internet]. Kementerian Kesehatan RI. 2017 Jun 28 [disitasi 2017 Jul 6]. Diunduh dari: http://www.depkes.go.id/article/ view/17062900001/tanggapan-kemenkes-atasmeninggalnya-dokter-stefanus-taofik-.html

3. Pusat Komunikasi Publik Sekretariat Jenderal Kementerian Kesehatan Republik Indonesia. Peran jumlah dan mutu tenaga kesehatan dukung percepatan MDGS dan implementasi JKN [Internet]. 2014 Mar 24 [disitasi 2017 Jul 5]. Diunduh dari: http://www.depkes. go.id/article/print/20143250004/peran-jumlahdan-mutu-tenaga-kesehatan-dukung-percepatanmdgs-dan-implementasi-jkn.html

4. Ikatan Dokter Indonesia. IDI: Persebaran dokter masih terpusat di kota [Internet]. 2013 Jun 17 [disitasi 2017 Jul 6]. Diunduh dari: http://www. idionline.org/berita-lengkap/idi-persebaran-doktermasih-terpusat-di-kota/

5. Royal College of General Practitioners. Patient safety implications of general practitioners workload [Internet]. 2015 Jul [disitasi 2017 Jul 6]. Diunduh dari: http://www.rcgp.org.uk/policy/ rcgp-policy-areas/ $\sim$ media/Files/Policy/A-Zpolicy/2015/RCGP-Patient-safety-implications-ofgeneral-practice-workload-July-2015.ashx

6. Xu W, Xie J, Wu H, Guo Z, Guo L, Feng X. The association between Chinese doctors workload and medical disputes. J Psychol Psychother. 2016 Apr 8;6:252. doi: 10.4172/2161-0487.1000252.

7. Lockley SW, Barger LK, Ayas NT, Rothschild JM, Czeisler CA, Landrigan CP. Effects of health care provider work hours and sleep deprivation on safety and performance. Jt Comm J Qual Patient Saf. 2007;33(11 Suppl):7-18. doi: 10.1016/S15537250(07)33109-7.

8. White C. Workload is rising and morale is falling among UK doctors, BMA survey shows [Internet]. 2012 Oct 16 [disitasi 2017 Sep 11]. Diunduh dari: http://careers.bmj.com/careers/ advice/view-article.html?id=20009283

9. Improving Doctors' Working Lives. Doctors' working hours: The basics [Internet]. 2009 Aug [disitasi 2017 Jul 6]. Diunduh dari: http://www. idwl.info/workinghours.html

10. Keputusan Menteri Kesehatan Republik Indonesia nomor 81 tahun 2004 tentang pedoman penyusunan perencanaan sumber daya manusia kesehatan di tingkat propinsi, kabupaten/kota serta 
rumah sakit. 2004. Diunduh dari: http://dinkes.

inhukab.go.id/wp-content/uploads/2015/04/

Kepmenkes-No-81-Th-2004-ttg-pedoman-

penyusunan-perencanaan-SDM-Kesehatan.pdf

11. Majelis Kehormatan Etik Kedokteran

Indonesia. Kode etik kedokteran tahun 2012.

Jakarta; 2012.

12. NHS Leadership Academy. Leadership

framework [Internet]. 2011 [disitasi 2017 Jul 6].

Diunduh dari: https://www.leadershipacademy.

nhs.uk/wp-content/uploads/2012/11/

NHSLeadership-Framework-LeadershipFramework-

Summary.pdf 